\title{
Medical History Event End Date Time
}

National Cancer Institute

\section{Source}

National Cancer Institute. Medical History Event End Date Time. NCI Thesaurus. Code C83330.

The date and time a medical history event has concluded. 